\title{
The Role of Corporate Boards in the Risk Management Function
}

\section{Latha Ramchand*}

C.T. Bauer College of Business, University of Houston, USA

\section{Introduction}

The events of 2008 and the effects of the same will stay with us for a long time. The financial crisis and the regulations resulting from the crisis have a significant impact on economic growth and behavior. The stress on risk controls, risk measurement, and risk management is here to stay. Whether it is Dodd-Frank Act or the implications of this act on financial institutions, it is clear that the focus on risk management is at an all-time high.

In many ways, the emphasis is not new. Enron resulted in Sarbanes Oxley and Section 404 that became law in 2002. This act requires management to attest to the adequacy of controls in the internal reporting structure. It also requires management to certify the veracity of its evaluations. Despite these provisions, the economy witnessed unprecedented risk taking by financial institutions prior to 2008. The sub-prime mortgage crisis resulted more from large appetites for risk than from financial mistakes. The story of Madoff bears testimony to the fact that despite the increased regulation, checks and balances did not obviously work.

Interestingly, it is not obvious that a regulated system would or should lower risky behavior and crises that follow. Psychologists find that under increased regulations, our behavior can be altered in a way that results in riskier outcomes, owing to 'risk compensation'. An example of risk compensation is the phenomenon that people who wear seatbelts and ride in cars equipped with airbags also tend to drive faster than those who do not. In addition, risk homeostasis alters our perceptions and hence, behavior when we see others following stricter rules. For instance, it has been found that motorists tend to drive more closely to bicyclists who wear helmets than those who do not. In other words, we alter our behavior and become less risk averse when we are in safer environments, or in environments that we believe to be safe. The belief is motivated by the fact that these environments have enforced safer behavior owing to compliance to external constraints. For these reasons, it is not obvious that a more rules-driven environment is associated with less risky behavior.

In short, Sarbanes Oxley, and Section 404, stricter mandates from the SEC post-Enron, did not eliminate the Madoffs of the world. Arguably, the role of the SEC is not to determine the level of risk appropriate for investors but rather, to ensure that investors have the requisite information they need to determine their own risk-return tradeoffs.

This paper examines how corporate boards can affect the types of shareholders investing in the firm and hence impact risk.

\section{Role of Corporate Boards}

The task of managing identified risks is shifting to corporate boards. In their third annual Board of Directors Survey, concerns about Risks Confronting Boards, Eisner Amper surveyed more than 190 board members from public and private companies. They find that an overwhelming number of directors (86\%) served on audit committees. In addition, the survey finds that other than financial risk, $66 \%$ of those surveyed identified reputational risk as their primary concern. This was followed by regulatory \& compliance risk (59\%), followed by IT risk (54\%) and CEO Succession Planning (53\%).
Drilling down into the notion of 'reputational risk', directors identified product, quality, liability and customer satisfaction as their top are of concern under reputational risk. This was followed by concerns about integrity, fraud, and ethics. Almost $79 \%$ of the respondents stated that their firms use internal audit processes to deal with these risks.

\section{Shareholders' Perceptions of Risk}

The other side of the equation on risks has to do with owners' perceptions of risk. While stock price changes may or may not mirror actual risk events of a firm, they are nevertheless, mirrors of performance for shareholder owners. How do these two risks, risks relevant to shareholders and risks deemed to be important to the board of directors, interact? Surely shareholder/owner perceptions are as important if not more.

Brian Bushee [1] examines the number of stocks in a portfolio versus the holding period to determine the relationships between the stock holdings and holding period return. He finds that "transiens" or investors, who hold several stocks for brief periods of time, account for $60 \%$ of all U.S. institutions. The next largest category is the "quasi indexers" who account for $30 \%$. This group holds several small positions for long holding periods. The remaining 10\% "dedicated holders" have large positions and long holding periods. Bushee finds that companies that provide earnings guidance and forecasts tend to have large numbers of momentum investors and are associated with greater stock price volatility. Hence, the type of investors that a company attracts affects its corporate performance and stock price volatility. These companies also spend less on average on R\&D in order to meet quarterly targets. Therefore, a change in disclosure practice has the potential to shift the composition of a firm's investor base away from transient investors and toward patient investors. What can firms do to change their shareholder base?

In a roundtable discussion on Risk Management, Corporate Governance, and the Search for Long-Term Investors [2], Don Chew highlights the story of Florida Power and Light (FPL). FPL was the first public utility to cut its dividend. In 1995, they reduced dividends by $33 \%$ and saw their stock price drop by $20 \%$. Shortly thereafter, however, (within a two week window) their stock price recovered to its predividend-cut level. In the meantime their shareholder base changed as well. The other example shared by Chew is that of Progressive Insurance which did away with earnings guidance and volunteered to share unaudited monthly P\&L statements. This change in disclosure

*Corresponding author: Latha Ramchand, Dean and Professor, Finance, C.T Bauer College of Business, University of Houston, USA, E-mail: ramchand@uh.edu

Received October 06, 2012; Accepted October 08, 2012; Published October 15 , 2012

Citation: Ramchand L (2012) The Role of Corporate Boards in the Risk Management Function. J Bus \& Fin Aff 1:e118. doi:10.4172/2167-0234.1000e118

Copyright: (c) 2012 Ramchand L. This is an open-access article distributed under the terms of the Creative Commons Attribution License, which permits unrestricted use, distribution, and reproduction in any medium, provided the original author and source are credited. 
Citation: Ramchand L (2012) The Role of Corporate Boards in the Risk Management Function. J Bus \& Fin Aff 1:e118. doi:10.4172/2167$0234.1000 \mathrm{e} 118$

Page 2 of 2

resulted in a decline in their stock price volatility by almost $50 \%$. Their shareholder base shifted to long term investors. Hence, it is possible and strategic to cultivate a shareholder base that believes in the company's strategy.

Hence, actions by the firm's management that affect risk perceptions (payout policy, earnings guidance policies) and that have to be approved by the board of directors affect the types of shareholders who invest in the firm. This also suggests that boards have a role in shareholder selection. Effective communications between the firm and its shareholder, as well as communications between the management and shareholders is crucial to the economic viability of a firm. The firm's overall business strategy informs the types of risks the firm faces. These risks must be considered as the board decides on other policies that can, through the types of shareholders, affect the valuation of the firm.
In short, corporate boards, via their influence on a firm's decisions, can influence the types of shareholders that invest in the firm. This role must not be overlooked in the management of risk. Effective communications between the board, management and the markets can help augment the efficacy of this role.

\section{References}

1. Bushee B (2004) Identifying and Attracting the "right" Investors: Evidence on the Behavior of Institutional Investors. Journal of Applied Corporate Finance 16: $28-35$

2. Walkling RA, Bauguess SW, Dunigan J, Park D, McGurn P, et al. (2010) Risk Management, Corporate Governance, and the Search for Long-Term Investors. Journal of Applied Corporate Finance 22: 58-74. 